\title{
Structural Unemployment and Technological Change in Canada, 1990-1999
}

\author{
Timothy C. SARgENT \\ Finance Canada
}

Dans cet article nous examinons l'impact d'un changement technologique sur le chômage et les emplois au Canada. Une attention particulière est portée sur le raisonnement selon lequel une augmentation de la vitesse du changement technologique est responsable de la faible performance de l'emploi au Canada dans les années 90. Nous décrivons quelques modèles économiques dans lesquels une telle possibilité pourrait se produire et ensuite examinons différentes données sur l'emploi au Canada afin de déterminer si les prédictions de ces modèles donnent une bonne représentation de la situation au Canada. Nous trouvons peu d'évidences selon lesquelles le changement technologique a eu un impact négatif sur le chômage et l'emploi au Canada durant les années 90.

In this paper we examine the impact of technological change on unemployment and employment in Canada. We focus in particular on the argument that an increase in the pace of technological change has been responsible for Canada's poor employment performance in the 1990s. We outline some economic models in which such a possibility could arise, and then examine a variety of labour market data for Canada to see whether the predictions from these models match the Canadian experience. We find that there is in fact little evidence that technological change had an important negative impact on overall unemployment and employment rates in Canada over the 1990s.

\section{INTRODUCTION}

$\mathrm{T}$ he decade of the 1990s was a difficult period in the Canadian labour market. A severe recession was followed by a sluggish recovery that only picked up speed in the last few years of the decade. Not only was average unemployment in the 1990s as high as in the 1980s, but there was a greater decline in the employment rate, and Canada's performance relative to the United States was much more disappointing.
What was the driving force behind this poor performance? Some commentators have suggested that restructuring associated with technological change and the transition to a "new economy" has played an important role. The Organization for Economic Cooperation and Development (OECD), in its influential Jobs Study (1994), has argued that the increase in the returns to skill has led to higher unemployment in Europe because the more regulated labour markets in these countries have led to lowskilled workers being priced out of the labour market 
and joining the ranks of the long-term unemployed. In the United States, however, low-skilled workers have remained employed but at lower wages. Indeed, the Study goes on to argue that "it is an inability of the OECD economies and societies to adapt rapidly and innovatively to a world of rapid structural change that is the principal cause of high and persistent unemployment." This view is sometimes known as the "OECD hypothesis" (Kuhn forthcoming). It has gained considerable popularity in policy circles, because it offers a unifying explanation for both higher unemployment in continental Europe, and an increase in skill premia and wage inequality in the United States.

Could an increase in technological change have increased structural unemployment in Canada in the 1990s? The purpose of this paper is to examine this question. We begin in the second section by taking a conceptual approach. Under what circumstances would economic theory suggest that technological change might increase structural unemployment? We examine two kinds of models: a simple demand and supply framework, in which institutions or other rigidities prevent wages from clearing the market; and a search/matching model, in which unemployment arises from the need for market participants for time to make an acceptable match.

Our next step is to turn to the different kinds of evidence which can be brought to bear on the question of interest. We begin our analysis of the data with an examination of aggregate market on labour market flows, and then we go on to look at data on industrial composition, occupational composition, and education. Finally, we offer some conclusions.

We narrow our focus on the data in two ways. First, we confine ourselves to Canadian data. The Canadian economy and Canadian institutions are sufficiently different from the United States and continental Europe that it is probably not safe to apply results from these countries to Canada. Second, we do not examine productivity data for direct evidence of skill-biased technical change or the tran- sition to a "New Economy" more generally. This is partly because there is an ongoing debate about the reliability of the price deflators used to produce productivity data. Because collectors of labour market data do not have to measure such intangible attributes as the quality of a good or service, labour market data are viewed as potentially a more reliable guide to trends in the economy than standard national accounts data (Murphy, Riddell and Romer 1998). Another reason for ignoring this kind of data is that our purpose is not to examine the evidence for an increase in technological change per se, but to see whether technological change can be held responsible for changes in overall unemployment and employment rates in the 1990s.

\section{Conceptual Overview}

In order to understand how technological change could have raised unemployment we first need a model of unemployment. Two kinds of models have proven popular in the literature. The first is the static supply and demand framework, in which rigid wages prevent the labour market from clearing; the second is the dynamic search/matching approach, in which unemployment arises because search is a time-consuming activity. The supply and demand framework is usually employed to model only skillbiased technical change, whereas the search/ matching approach can be used to model both biased and unbiased technical change.

\section{Models of Skill-Neutral Technical Change}

Despite the attention given to skill-biased technical change in the recent literature on technological change and the labour market, it is important to recognize that technical change that is not skill-biased can also increase unemployment. If the rate of technical change starts to grow more quickly in some industries, then we would expect that labour would be reallocated from the slower to the faster growing sectors. Now, in a simple static demand and supply framework with homogenous workers, there would be no unemployment because this reallocation would 
take place instantaneously, with no intervening period of unemployment. In order to model unemployment in such a context, we require a dynamic model that recognizes that labour reallocation takes time. Such a framework is, of course, provided by search/ matching models of the labour market. In a standard model of this kind, such as Pissarides (1990), an increase in relative productivity is modelled as a relative price shock that leads to job creation in some sectors, but an increase in job destruction in others. Unemployment will rise and job tenure will fall, as a result of layoffs in the contracting sector. Vacancy rates will rise, however, because with a positive technological shock, the number of vacancies created in the expanding sectors will be greater than the reduction in the number of vacancies in the declining sector.

Empirically, what should we observe? Both unemployment and vacancy rates should rise, leading to an outwards shift in the Beveridge curve, the negatively sloped relation between vacancies and unemployment that one normally observes in the absence of movements in the rate of structural change. ${ }^{1}$ In the data on labour market flows, we should observe an increase in job destruction, and a fall in average job tenure. If the shock is affecting some industries more than others, we should also observe an increase in the sectoral reallocation of labour.

\section{Models of Skill-Biased Technical Change}

The original papers in the skill-biased technical change literature, such as Katz and Murphy (1992) and Juhn, Murphy and Pierce (1993), were written to explain changes in wage inequality. For this reason the models used in these papers are based on a simple supply and demand framework that abstracts from unemployment and considers only movements in employment and wages. These earlier studies also abstract from any labour market institutions that might constrain the response of wages or employment to market forces. The main result that flows from these simple models of technical change is that skill-biased technical change should increase the relative demand for skilled labour, which should lead to higher relative wages. If labour supply curves for the different kinds of labour are upward sloping, then the employment of skilled labour relative to unskilled labour will rise.

What is important to note about this line of argument is that it does not necessarily imply that the absolute level of employment of unskilled workers will fall as a result of a technological increase biased toward skilled labour, only the relative level of employment. What is required for an absolute fall in the employment level of unskilled labour is for labour demand to fall in absolute, rather than relative terms. One way in which this could happen is if there is a third factor of production, say capital, that can be used with either kind of labour. In this case a skill-biased technical change could induce capital to move away from unskilled labour toward skilled labour, lowering the capital-unskilled labour ratio and making unskilled labour less productive than before in absolute terms. ${ }^{2}$ As a result, the demand for unskilled labour will fall, and, if the supply of labour is not perfectly elastic, the employment levels of unskilled labour will fall as well. Note though that even in this case overall employment need not fall; this would require additional assumptions about the relative elasticity of labour supply curves and the relative shares of each kind of labour.

In the simple supply and demand model that we have been discussing up to now there is no unemployment: wages adjust to eliminate any excess supply of labour. A simple way of motivating unemployment in such a model is to assume that there are institutions, such as unions and legal minimum wages, that prevent wages from adjusting to clear the market. In this context a shift in demand away from low-skilled workers will tend to increase the unemployment rate of these workers, and lower the unemployment rate of more skilled workers. Because labour market institutions tend to have more impact on the wages of lower-waged workers, it is reasonable to suppose that in general the overall unemployment rate will rise. However, these constraints on wages will reduce the increase in wage 
inequality which would occur in the unconstrained demand and supply model.

What is appealing about the supply and demand model is that it can explain how the same demand shock can affect in different ways the labour markets of countries with different wage-setting institutions. For example, as noted in the introduction, many authors have argued that increases in wage inequality in the United States, and increases in unemployment in continental Europe, can be explained by the same skill-biased demand shock.

Similar predictions about the impact of a skillbiased demand shift can be obtained in search/ matching models of the labour market. For example, Mortensen and Pissarides (1999) show that if a skill-biased demand shock is modelled as an increase in the dispersion of the productivity of individual workers, then such a shock will increase unemployment significantly more in a labour market with generous unemployment insurance benefits and stringent job-protection legislation than in a labour market that does not have these features. Although unemployment falls for skilled workers, this increase is more than offset by the increase in unemployment for the less skilled.

Acemoglu (1999) also examines the impact of a skill-biased demand shift in the context of a search/ matching model. Unlike Mortensen and Pissarides (1999), however, Acemoglu assumes that skilled workers are more costly to recruit, and that firms must choose what kind of jobs to advertise. In this model, a skill-biased demand shift can move the economy from a pooling equilibrium, where jobs are of similar productivity and little screening is done, to a separating equilibrium, where jobs for the higher skilled pay significantly better, but where firms must pay a high level of screening costs in order to ensure that high-skill vacancies are filled by high-skill applicants. In this model, unemployment rates for both the high and the low skilled rise, because each group must search harder for jobs that are appropriate to them. A further prediction of the model is that the unemployment rate will rise for a given vacancy rate, because firms are more stringent about whom they hire for a particular vacancy. This implies an outward shift in the Beveridge curve, as with models of skill-neutral technical change.

\section{Evidence from Data on Labour Market FLows}

We now turn to an assessment of the evidence for and against the hypothesis that technological change has negatively affected aggregate unemployment and employment in Canada over the 1990s. We begin with some evidence on labour market flows.

\section{The Beveridge Curve}

In the previous section we argued that in a search/ matching model an increase in technical change should lead to an outward shift in the Beveridge

FIGURE 1

The Canadian Beveridge Curve

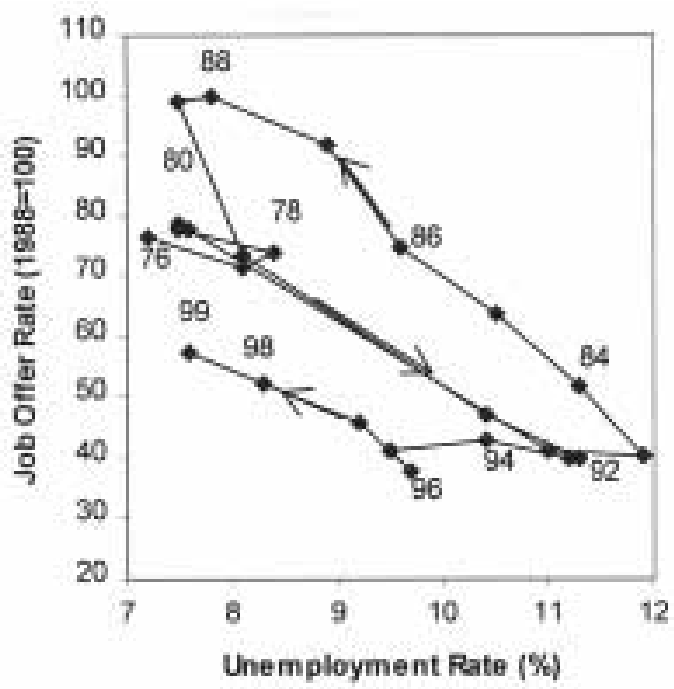

Note: The Unemployment Rate is taken from Labour Force Historical Review (71F0004XCB). The Job Offer Rate is the ratio of the Help Wanted Index to the total Labour Force, indexed so that $1988=100$. 
curve, the relation between vacancy rates and unemployment rates. Canada no longer has a direct measure of vacancies; however, an indirect measure can be constructed using the Help Wanted Index (see Fortin 1998). ${ }^{3}$ Figure 1 shows the resulting Beveridge curve.

The data in Figure 1 do show an outward shift in the Beveridge curve, but only in the late 1970s. In the 1990s the Beveridge curve has shifted inwards, with unemployment now significantly lower at a given level of vacancies. Of course, these shifts are not necessarily anything to do with technical change. Changes in labour market institutions can also shift the Beveridge curve. One such candidate is Canada's Employment Insurance (EI) system, which was made more generous in the 1970s, but was cut back considerably in the 1990s. A more generous EI makes the unemployed more selective about accepting job offers, resulting in a greater unemployment rate for a given vacancy rate and thus a rightwards shift in the Beveridge curve.

\section{Hiring and Separation Rates}

Other evidence on the impact of technological change on the labour market is provided in Picot and Lin (1997). The authors use longitudinal administrative data to examine hiring, quit, and layoff rates over the period 1978-94. The paper finds that job creation and destruction rates fell in the early 1990s, rather than rising as predicted by the model of skill-neutral technical change outlined in the second section. There is therefore no evidence from these data that the pace of technical change increased.

Picot and Lin's conclusions are corroborated by data on job tenure. If there were really more job destruction than before, we would expect to see average job tenure fall, because the probability of holding onto one's job would fall. However, as Picot and Heisz (this volume) show, average job tenure has actually risen somewhat. This is confirmed by Green and Riddell (1996), who also find that job instability has not increased since 1976.

\section{EvidenCe From Data on IndUSTRIAL COMPOSITION}

In the second section we suggested that if technical change has affected employment in Canada, we might expect to see an increase in the extent to which labour is reallocated across industries. One measure of this that has proven popular in the literature is the sectoral shift measure of Lilien (1982). Lilien's measure is the dispersion of employment, defined as

where $x_{i t}$ is the employment level of industry $i$ at time $t, X_{t}$ is total employment at time $t$, and $N$ is the total number of industries. $\sigma_{t}$ measures the extent to which employment is shifting between different industries: it will detect structural change in the economy to the extent that this structural change is characterized by workers moving from declining to expanding industries.

To implement the Lilien measure empirically we constructed three time series of cross-sections of $\mathrm{Ca}$ nadian industries. The first is a nine-industry panel of business sector industries at the one-digit level. We have data on this panel from 1921 to 1996. The second data set is a 31-industry panel of business-sector industries at the two-digit level, from 1950 to 1963 , and the third is a similar panel of 34 industries from 1961 to 1996 . The employment dispersions constructed from these data are shown in Figure 2.

Although the three series are quite volatile, they are similar, with the nine-industry series tending to underestimate slightly the levels of the 31- and 34industry series. It is apparent that there were much greater flows between industries in the 1930s and 1940s than subsequently, and somewhat greater flows in the 1950s and early 1960s than in the 1970s, 1980s, and 1990s. This points to a less rapid pace of structural change in Canada since the early 1960s. 
FIGURE 2

The Lilien Employment Dispersion Measure for Three Panels of Canadian Industries

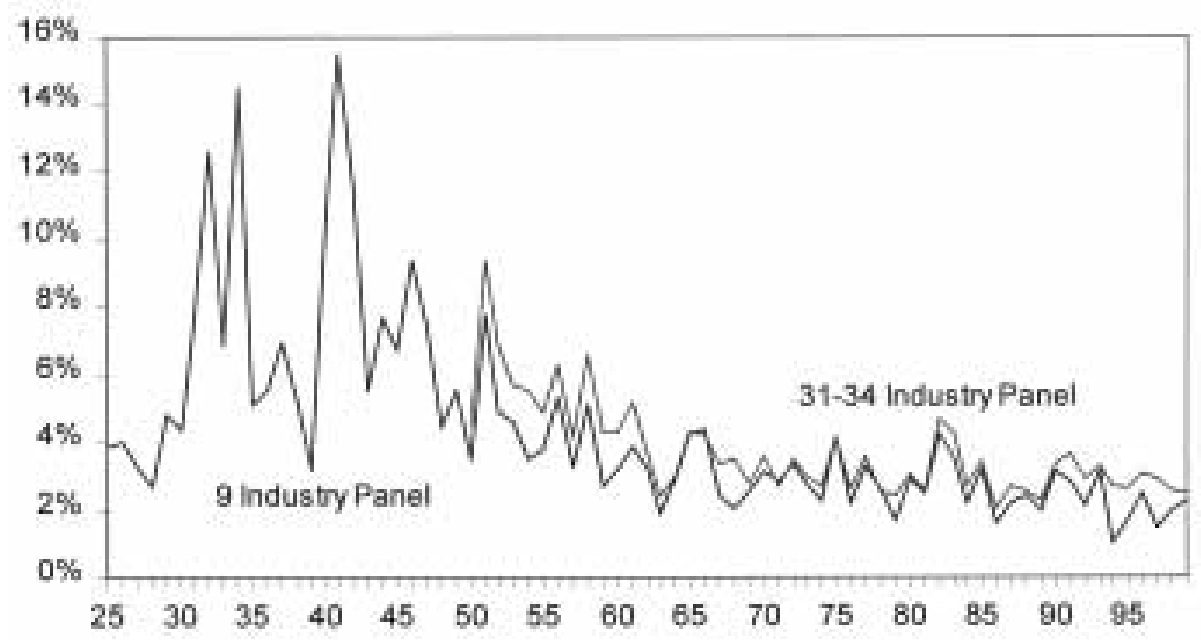

Note: The 31-34-industry panel consists of a 31-industry panel from 1950-60, and a 34-industry panel from 1961-99. Sources: Review of Employment and Payrolls (Cat. No. 72-201), Employment Payrolls and Hours (Cat. No. 72-202).

The extent to which the Lilien index measures structural change in the economy is controversial: some have argued that one would not expect a recession to affect all industries equally, and the high level of the index in the 1930s is more likely a result of cyclical factors, unless one thinks that the Great Depression was the result of technology shocks. Nevertheless, it is clear that there is little support for the hypothesis of greater structural change from these data. Our results are consistent with Gera and Mang (1997), who find a slightly declining rate of structural change in the Canadian economy between 1971 and 1991 using a similar methodology.

\section{EVIDENCE FROM Data ON OCCUPATIONAL COMPOSITION}

\section{Evidence from Payroll Data}

Berman, Bound and Griliches (1994) use data from the Annual Survey of Manufactures (ASM) to examine the skill-biased technical change hypothesis. They find that the proportion of non-production workers in US manufacturing plants increased from 27 percent in 1959 to 35 percent in 1989, and that the rate of increase rose after 1973. The same pattern is also evident in total payrolls, which Berman et al. argue to be a better indicator of demand shifts. Non-production workers are defined as "those engaged in supervision (above the working foreman level), installation and servicing of own product, sales, delivery, professional, technical, administrative etc." (1994, p. 369). Using labour market data, the authors argue that there is a close correspondence between educational attainment, white-collar status, and being a non-production worker. Because the shift toward non-production workers occurred within the 450 different categories of manufacturing industry, and was not the result of shifts in employment across industries, the authors conclude that the shift was caused by skill-biased technical change, rather than increased foreign competition or the increase in defence spending. These latter influences would have tended to change the composition of demand across industries, which does not seem to have happened. 
In order to see whether Berman et al.'s results apply to Canada, we first examined data from Canada's ASM. These data are very similar to the US data used by Berman et al. Figure 3 shows the proportion of non-production workers in Canadian manufacturing industries, and non-production workers' share of total payrolls. It is clear that in Canada there has been a marked downward trend in the proportion of non-production workers, both as a share of total employment and as a share of payrolls, since 1961. There is also an evident cyclical pattern, with the proportion of non-production workers tending to rise during recessions, as one would expect if they were a relatively fixed factor.

These results from the ASM are confirmed by an examination of data on all industries (except agriculture) from the Survey of Payrolls, Employment and Hours (SEPH), although these data only go back to 1983 . Figure 4 shows the share of salaried workers in total payrolls in manufacturing, in all industries covered by SEPH, and as a proportion of

\section{FIGURE 3}

Non-Production Workers' Share in Manufacturing Employment and Payrolls

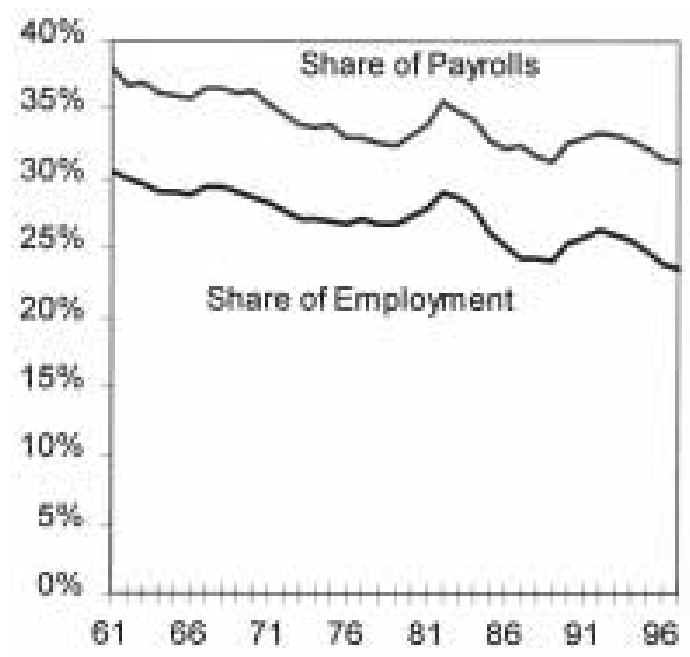

Source: Manufacturing Industries of Canada: National and Provincial Areas (Cat. No. 31-203).
FIGURE 4

Salaried Workers' Share in Total Payrolls

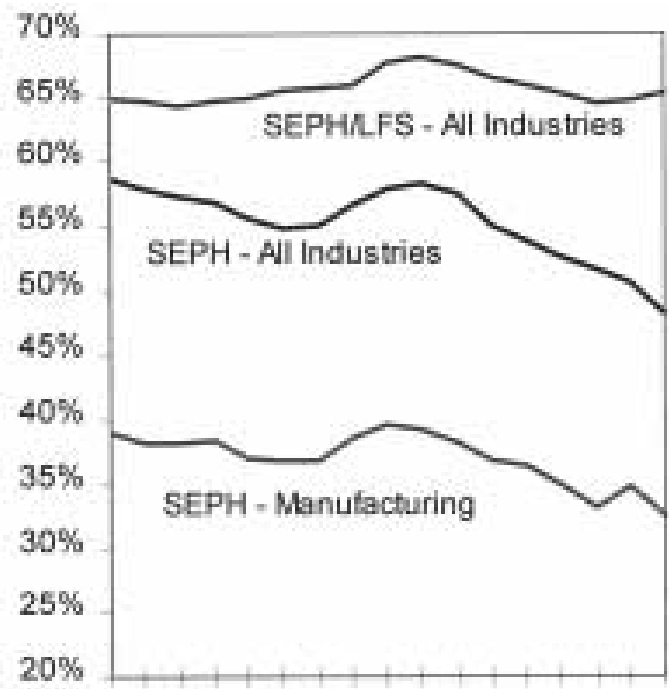

$\begin{array}{lllllllll}83 & 85 & 87 & 89 & 91 & 93 & 95 & 97 & 99\end{array}$

Source: Employment, Earnings and Hours (Cat. No. 72201), Labour Force Historical Review (71F0004XCB).

total non-agricultural employment as measured by the Labour Force Survey (LFS). For the latter measure we have assumed that workers not covered by the SEPH, typically self-employed workers, are salaried. The trends in the SEPH data are similar to those in the ASM data: the share of white-collar workers, though quite cyclical, is trending gently downwards. It appears therefore that to the extent that white-collar status is an indicator of skill, these data are difficult to reconcile with an increase in the rate of skill-biased technical change.

\section{Evidence from Household Survey Data}

Another way of measuring occupational change which has received attention in the popular media is to look at the top ten most common occupations at the four-digit level from census data (The Globe and Mail, 18 March 1998). The list is presented in Table 1 for 1971 and 1996 (the most recent year available). It is evident that there has been little change in the top ten occupations between 1971 and 
TABLE 1

Top Ten Occupations in Canada by Sex, 1971 and 1996

Men

1971 1996

\begin{tabular}{rlrlr}
\hline 1 & Truck driver & 198,140 & Truck driver & 222,795 \\
2 & Janitor / caretaker & 114,305 & Retail sales clerk & 215,345 \\
3 & Vehicle mechanic & 111,350 & Janitor / caretaker & 185,035 \\
4 & Farm worker & 108,680 & Retail manager & 179,645 \\
5 & Carpenter & 99,635 & Farmer & 176,985 \\
6 & Accountant / auditor & 87,365 & Sales representative & 131,225 \\
7 & Retail sales clerk & 82,275 & Vehicle mechanic & 127,185 \\
8 & Soldier - other ranks & 67,710 & Material handler & 119,135 \\
9 & Bookkeeper / accounting clerk & 65,375 & Carpenter & 112,965 \\
10 & Construction labourer & 61,775 & Construction labourer & 104,110
\end{tabular}

Women

1971

1996

\begin{tabular}{rlrll}
\hline 1 & Office secretary & 239,810 & Retail sales clerk & 339,025 \\
2 & Retail sales clerk & 159,825 & Office secretary & 311,835 \\
3 & Bookkeeper & 136,435 & Cashier & 235,585 \\
4 & Elementary school teacher & 120,165 & Registered Nurse & 220,625 \\
5 & Waitress & 105,410 & Accounting Clerk & 219,895 \\
6 & Cashier & 103,455 & Elementary school teacher & 187,070 \\
7 & Farm worker & 93,505 & Waitress & 176,310 \\
8 & Registered Nurse & 90,850 & Office clerk & 173,175 \\
9 & Typist & 84,875 & Babysitter & 134,560 \\
10 & Office clerk & 79,335 & Receptionist & 118,985 \\
\hline
\end{tabular}

Sources: Statistics Canada, The Daily (17 March 1998); 1971 Census of Canada Vol. III (94-729).

1996. For men, soldier, accountant, and accounting clerk have dropped out of the top ten, to be replaced by retail manager, material handler, and sales representative. For women, typist, farm worker, and bookkeeper have been replaced by babysitter, receptionist, and accounting clerk. Otherwise there is little evidence of change in occupational patterns.

The picture of occupational stability in employment patterns is confirmed by LFS data on employ- ment rates by occupation, shown in Figure 5 below. There were small declines in the proportion employed in traditional blue-collar occupations such as trades, transport, and equipment, but this was partly offset by increases in the service occupations. Some white-collar categories such as management lost a little ground, but this was more than offset by an increase in natural and social science occupations. Overall though, these data confirm the impression of relative occupational stability provided by the census data above. 


\section{FIGURE 5}

Occupation Group as a Proportion of Total Employment

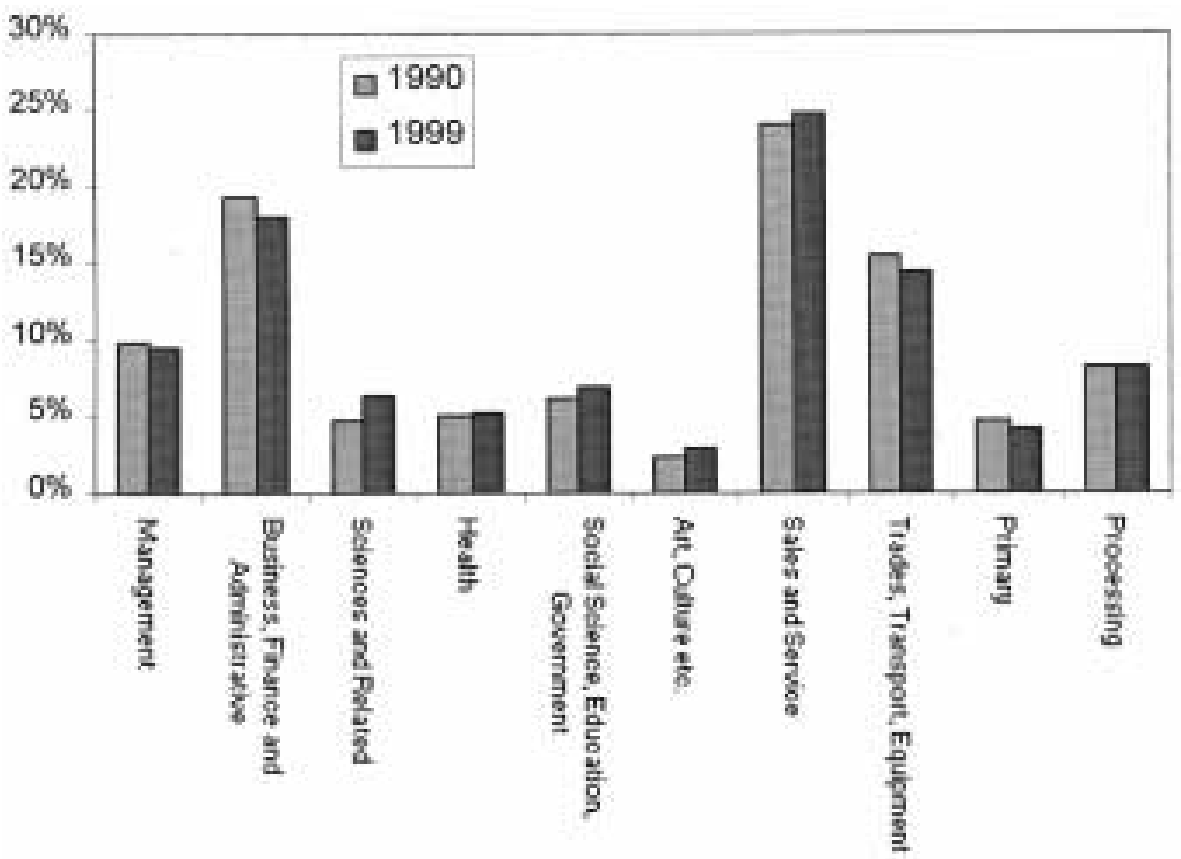

Source: Labour Force Historical Review (71F0004XCB).

What about unemployment rates? Figure 6 shows unemployment rates by occupation for 1990 and 1999. ${ }^{4}$ Although the unemployment rate for primary occupations has risen from 8.6 percent to 9.8 percent, unemployment rates for other blue-collar jobs such as trades, transport, and equipment, which includes construction workers, has fallen significantly from 10.1 to 7.6 percent. Indeed, the unemployment rate fell for almost all occupations. What prevented the overall unemployment rate from falling was a large increase in the number of those classed as having no occupation: youth, or the long-term unemployed. Because we do not know the occupation of the latter, the evidence presented in Figure 8 should be viewed as suggestive. Nevertheless, taken with the other evidence on occupation in this section, it does suggest that there is little indication of radical change in the occupational structure of the Canadian economy.

\section{Evidence From Data on Educational COMPOSITION}

We now turn to data on educational attainment. This is perhaps the most popular definition of skill used by researchers in the debate over the impacts of skillbiased technical change. In this section we examine data on unemployment and employment rates taken from the Labour Force Survey. Because the definitions of educational attainment in this survey changed in 1990, we present data separately for before and after this break.

\section{Evidence from Data on Unemployment Rates} We begin first with changes in unemployment rates by education level over the 1990s, shown in Figure 7. Unemployment rates rose for all education groups in the early 1990s, peaking in 1993, and then 


\section{FIGURE 6}

Unemployment Rates by Occupation, 1990 and 1999

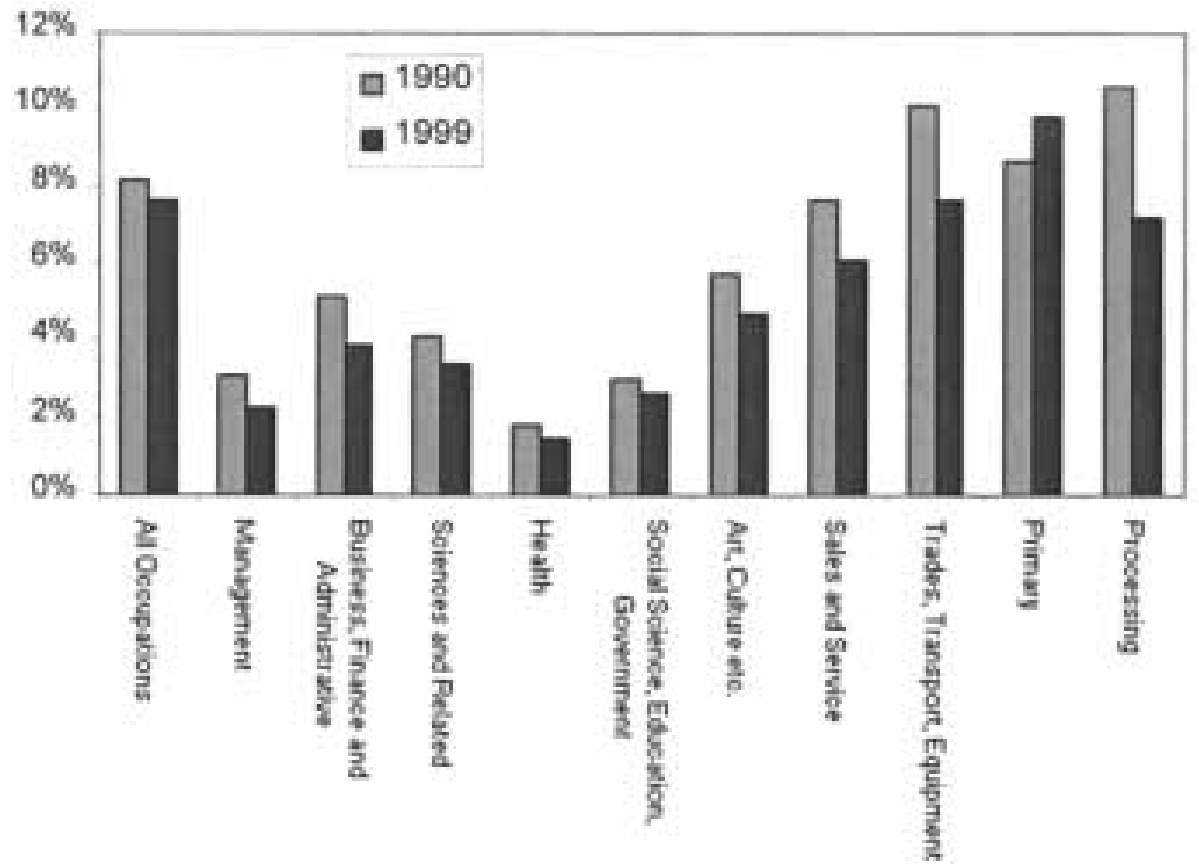

Source: Labour Force Historical Review (71F0004XCB).

falling until 1995. Then rates tended to rise slightly before falling in the late 1990s. In absolute terms, the rise in unemployment was greatest for those with a lower education. However, the less-educated had a higher unemployment rate at the start of the recession, and in proportionate terms the rise was very similar for all educational groups. The unemployment rate for those with less then high school in 1993 was 140 percent of its 1990 level, whereas the unemployment rate for those with a university education was 155 percent of its 1990 level.

Figure 8 shows that the pattern in unemployment rates by education group observed in the 1990s was very similar to that observed in the 1980s, although we must make allowances for the change in the definitions of the different groups mentioned above. Once again, unemployment rates rose most in absolute terms for the least-educated, but in proportion- ate terms the change was very similar. At the trough of the recession in 1983, the unemployment rate for those with ten years or less of education was 149 percent of its 1981 level, whereas the unemployment rate for those with a university education was 161 percent of its 1981 level.

\section{Evidence from Data on Employment Rates}

The story told by the data on employment rates is somewhat different. Figure 10 shows that employment rates for those with a high school education or better behaved quite similarly in the 1990s. However, employment rates for those who had not completed high school or had no postsecondary education, already very low, fell further than for those with more education, and has shown less sign of recovery.

Figure 9 shows employment rates by education for the 1980s. During this period, employment rates 


\section{FIGURE 7}

Unemployment Rate by Education, 1981-1989

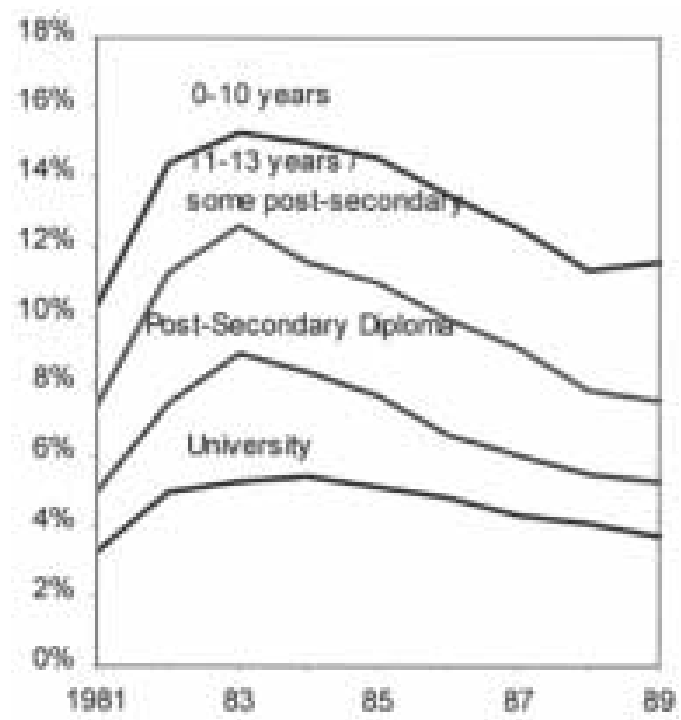

Note: "Post Secondary Diploma" does not include persons with a diploma who did not graduate from high school.

Source: Labour Force Historical Review (71F0004XCB).

for those without a university education fell somewhat further than the employment rate for those with university education, however, in the case of those with ten or more years of education, employment rates recovered more strongly after 1983. However, there was little recovery for those with ten years or less of education. Then, as in the 1990s, the employment rate for the least educated fell and the drop was not reversed by the recovery. However, the fall in the 1990s was somewhat greater: employment rates fell by 4.3 percentage points between 1981 and 1984, compared with 6.3 percentage points between 1990 and 1993.

Thus it appears that the employment rates of the least educated fell more in the 1990s than in the 1980s - although one must bear in mind that there are differences in the definitions of the two groups before and after 1990. Before concluding that this greater decline in employment rates is evidence of
FiguRE 8

Unemployment Rate by Education, 1990-1999

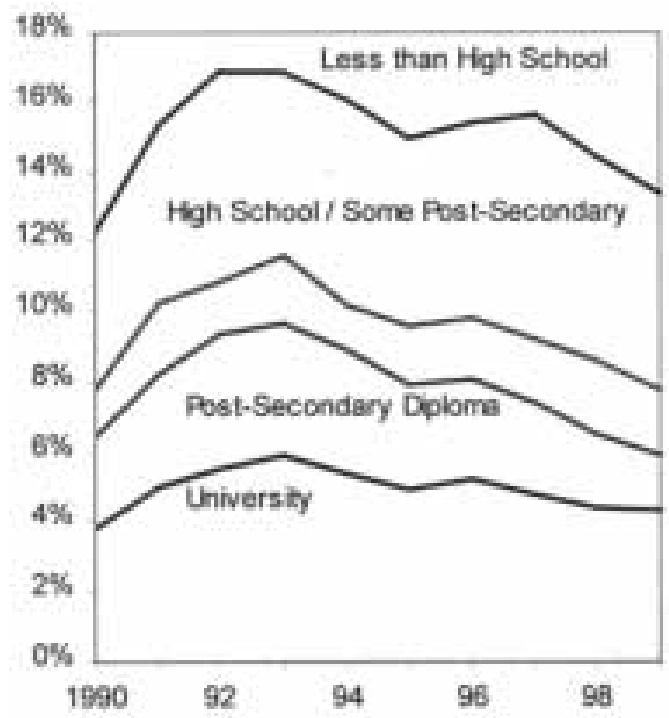

Note: "Post Secondary Diploma" includes all persons with a diploma, whether or not they graduated from high school.

Source: Labour Force Historical Review (71F0004XCB).

the impact of technological change, one must eliminate possible supply-side explanations. In particular, the educational level of the Canadian population was rising rapidly during this period, and the fall in employment rates of the least educated must reflect in part the fact that the average mature person with low education is much older and therefore much closer to retirement than the more educated.

Figures 11 and 12 show employment rates for workers aged 25-44 for the periods 1981-89 and 1990-99. Here there is much less evidence that those with less than a high school education fared relatively worse in the 1990s than they did in the 1980s. On the contrary, the magnitudes of the declines in employment rates are fairly similar in the two recessions. The main difference between the two time periods is the slower recovery of employment rates for all groups in the 1990s. 
FIGURE 9

Employment Rates by Education, 1981-1989

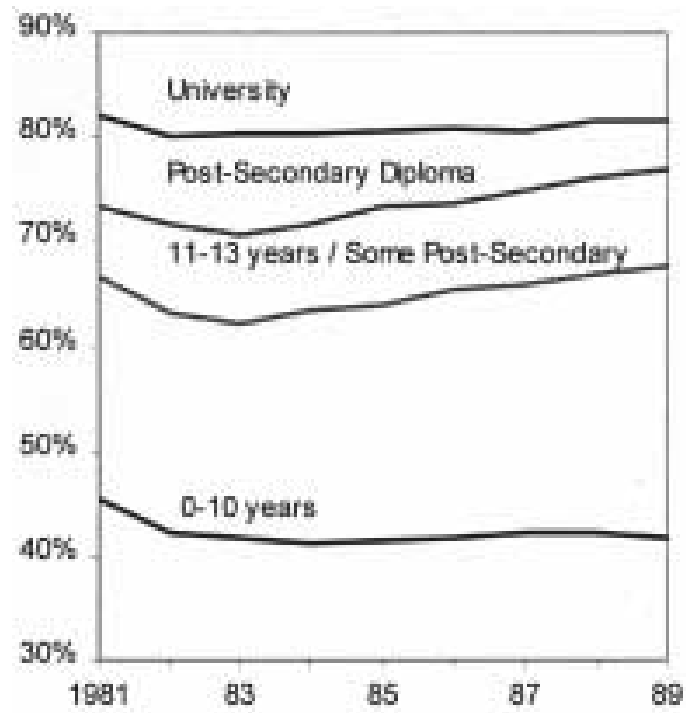

Note: "Post Secondary Diploma" does not include persons with a diploma who did not graduate from high school.

Source: Labour Force Historical Review (71F0004XCB).

\section{Conclusions}

In the second section, we laid out two sets of models in which an increase in technological change could increase unemployment and reduce employment. We then went on in subsequent sections to confront the models with data on labour market flows, industrial composition, occupational composition, and educational composition. How have the models fared in their confrontation with the data? In particular, how plausibly can these models explain the high unemployment and low employment of most of the 1990s?

The first set of models discussed were models of skill-neutral technical change, in which higher unemployment is primarily a shorter term phenomenon associated with the reallocation of labour from contracting to expanding sectors. These models predict
FIGURE 10

Employment Rates by Education, 1990-1999

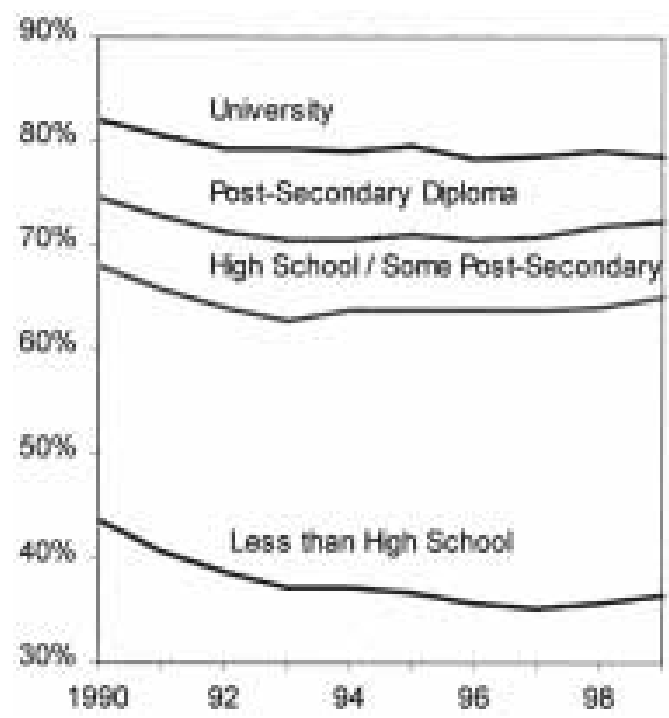

Note: "Post Secondary Diploma" does not include persons with a diploma who did not graduate from high school.

Source: Labour Force Historical Review (71F0004XCB).

that the process of reallocation should be associated with an increase in permanent separations, a fall in average job tenure, an increase in the sectoral reallocation of labour, and, at least in some models, an outward shift in the Beveridge curve. In fact, in the 1990s in Canada, permanent separations have fallen, job tenure has risen, the Beveridge curve has shifted in, and there is no apparent change in the rate at which labour is moving between industrial sectors. This is strong evidence against the hypothesis that skill-neutral technical change has had an important impact on aggregate unemployment in Canada in recent years.

Do models of skill-biased technical change provide a more plausible explanation for high unemployment and low employment in Canada in the 1990s? Both the simple supply and demand model, and the more sophisticated search/matching model 
FIGURE 11

Employment Rates by Education, 1981-1989, Ages 25-44

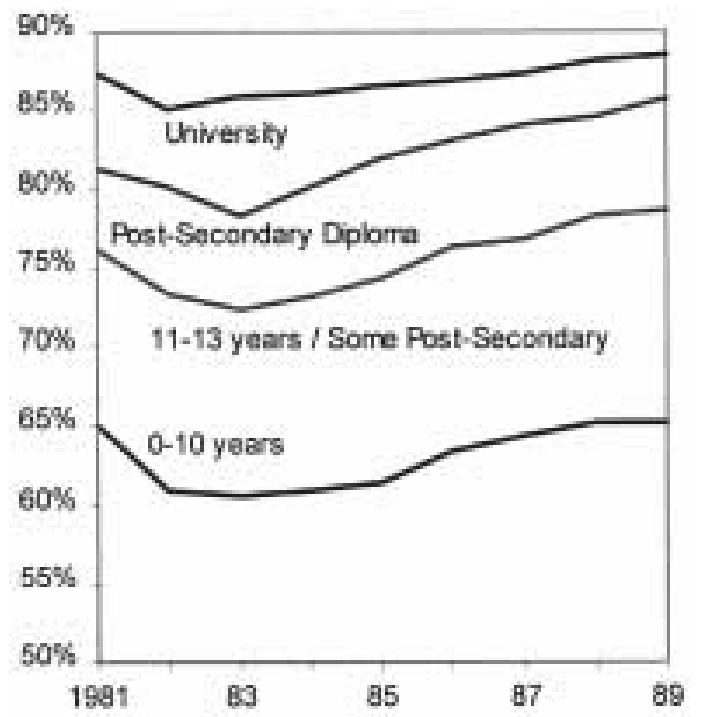

Note: "Post Secondary Diploma" does not include persons with a diploma who did not graduate from high school.

Source: Labour Force Historical Review (71F0004XCB).

of Mortensen and Pissarides (1999) imply that the unemployment rate of skilled workers should fall. This did not happen in the 1990s: instead the unemployment rate of more-educated workers rose in the early 1990s and then declined, following the same pattern as unemployment rates for less educated workers. Employment rates also fell for all education levels, although here the least-educated did somewhat worse in the 1990s. However, the latter may well be a result of the fact that the less-educated are older on average, and thus closer to retirement. The pattern of changes in employment rates for those aged 25-44 in the 1990s was similar to the 1980s. This pattern is confirmed by an analysis of the occupational data, which shows little change in the composition of employment, and little tendency for unemployment rates to rise relatively more for the less skilled.
FIGURE 12

Employment Rates by Education, 1990-1999, Ages 25-44

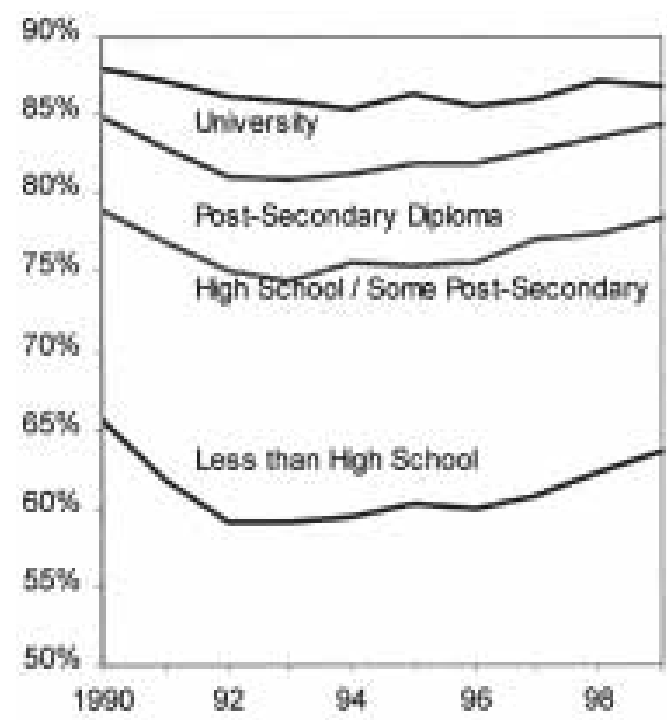

Note: "Post Secondary Diploma" does not include persons with a diploma who did not graduate from high school.

Source: Labour Force Historical Review (71F0004XCB).

Thus, not only did unemployment rates for skilled workers not fall, as predicted by the supply and demand model and the Mortensen and Pissarides model, they rose, and at the same rate as unemployment rates for the less-educated. Furthermore, there was little difference between the 1990s and the 1980s. We must therefore conclude that these models cannot then give us a convincing explanation of the behaviour of aggregate unemployment or employment trends in Canada in the 1990s.

The predictions of Acemoglu's (1999) model are somewhat different. In his framework, skill-biased technical change can increase unemployment for both skilled and unskilled workers, as firms become more choosy about whom they will hire. Acemoglu's model is somewhat hard to examine empirically, because it does not make sharp predications about relative unemployment and employment rates for 
skilled and unskilled workers. (It does seem unlikely though that these would remain stable, as actually observed in the data). However, Acemoglu's model does predict, as with the models of skill-neutral technical change, that unemployment should rise for a given level of vacancies so that the Beveridge curve shifts out. As we have seen though, the reverse occurred in the 1990s. As a result, this model too does not seem to explain Canada's unemployment experience over the 1990s.

We therefore conclude that technological change cannot be held responsible for the poor overall performance of the Canadian labour market over the 1990s. There is no evidence of more restructuring due to technological change, nor is there evidence that a skill-biased demand shift has interacted with labour market institutions to increase unemployment.

It is important to be clear about what we are not claiming. We are not saying that there is no evidence of technological change, or that it has not had an impact on the labour market. There have clearly been important technological changes over the 1990s, and some authors, such as Beaudry and Green (1999) have argued that these changes are associated with increases in skill premia in Canada in the 1990s. What we are arguing is that there has been little negative impact of such changes on overall employment and unemployment; whether wage inequality has increased or not and if so why is still not clear and that is partly why we have chosen to stay away from this kind of evidence. Also, while an increase in wage inequality might be an indication of skillbiased technical change, it might also indicate that relative wages in the Canadian labour market are flexible enough to offset the negative impacts of such a shock on employment and unemployment. Furthermore, it could be that the negative impacts of technological change on less-educated workers have been offset by other factors, such as an increase in the supply of educated workers, as argued by Murphy, Riddell and Romer (1998). Finally, our focus is on the overall labour market: specific groups or regions could have been severely affected, but this might not show up clearly in the aggregate statistics.

\section{Notes}

The author would like to thank Steven James, Fred Gault, Jeremy Rudin and participants at the Statistics Canada Economic Conference 99 in Ottawa for helpful comments. A previous version of this paper circulated under the title "Skill-Biased Technical Change and the Canadian Economy." The views expressed in this paper are the author's and ought not to be attributed to the Department of Finance.

${ }^{1}$ These predictions flow from a simple search/matching model in which the job-separation rate is assumed to be an exogenous parameter. This model can be generalized, as in Mortensen and Pissarides (1994), to allow for endogenous job destruction. In this case it is possible that the Beveridge curve might not shift out because unemployment may not rise. However, job destruction and creation would both rise, and job tenure would still fall.

${ }^{2}$ See Beaudry and Devereux (1996, p.7) for a more rigorous explanation.

${ }^{3}$ See Zagorsky (1998) for evidence that the help wanted indices can serve as good proxies of vacancy rates over long periods of time.

${ }^{4}$ It is difficult to get a picture of longer term trends from these data, as they are only available on a consistent basis back as far as 1987 .

\section{REFERENCES}

Acemoglu, D. 1999. "Changes in Unemployment and Wage Inequality: A New Theory and Some Evidence," American Economic Review 89(5):1259-78.

Beaudry, P. and D.A. Green. 1999. "What is Driving U.S. and Canadian Wages: Exogenous Technical Change or Endogenous Choice of Technique?" unpublished paper.

Beaudry, P. and M.B. Devereux. 1996. "Exploring General Equilibrium Implications of Skill-Biased Technological Change," Discussion Paper No. 96-01. Vancouver: Department of Economics, University of British Columbia. 
Berman, E., J. Bound and Z. Griliches. 1994. "Changes in the Demand for Skilled Labour within U.S. Manufacturing: Evidence from the Annual Survey of Manufactures," Quarterly Journal of Economics 59(2):367-98.

Fortin, P. 1998. "What Is the Correct Interpretation of the Great Canadian Slump of the 1990s?" unpublished paper.

Gera, S. and K. Mang. 1997. "The Knowledge-Based Economy: Shifts in Industrial Output," Working Paper No. 15. Ottawa: Industry Canada.

Green, D. and W.C. Riddell. 1996. "Job Durations in Canada: Is Long Term Employment Declining?" Discussion Paper No. 96-19. Vancouver: Centre for Research on Economic and Social Policy, University of British Columbia.

Juhn, C., K.M. Murphy and B. Pierce. 1993. "Wage Inequality and the Rise in Returns to Skill," Journal of Political Economy 101(3):410-42.

Katz, L.F. and K.M. Murphy. 1992. "Changes in Relative Wages 1963-1987: Supply and Demand Factors," Quarterly Journal of Economics 57(1):35-78.

Kuhn, P. 2000. "Canada and the 'OECD Hypothesis': Does Labour Market Inflexibility Explain Canada's High Level of Unemployment?" in Public Policies in a Labour Market in Transition, ed. W. C. Riddell and F. St-Hilaire. Montreal: Institute for Research on Public Policy, forthcoming.

Lilien, D. 1982. "Sectoral Shifts and Cyclical Unemployment," Journal of Political Economy 90(4):777-93.

Mortensen, D.T. and C.A. Pissarides. 1999. "Unemployment Responses to 'Skill-Biased' Technology Shocks: The Role of Labour Market Policy," Economic Journal 109(2):242-65.

Murphy, K.M., W.C. Riddell and P.M. Romer. 1998. "Wages, Skills and Technology in Canada and the United States and Canada," NBER Working Paper No. 6638. Cambridge, MA: National Bureau of Economic Research.

Organization for Economic Cooperation and Development (OECD). 1994. The Jobs Study. Paris: OECD.

Picot, G. and Z. Lin. 1997. "Are Canadians More Likely to Lose their Jobs in the 1990s?" Working Paper No. 96. Ottawa: Analytical Studies Branch, Statistics Canada.

Pissarides, C.A. 1990. Equilibrium Unemployment Theory. Oxford: Basil Blackwell.

Zagorsky, J.L. 1998. "Job Vacancies in the United States: 1923 to 1994," Review of Economics and Statistics 80(2):338-45. 